\title{
UTILIZATION OF COMPUTER SIMULATION FOR SOLUTION OF FLOOD-CONTROL RESEVOIR PROTECTION FUNCTION
}

\author{
Jan Fikejz ${ }^{(a)}$, Ladislav Roušar ${ }^{(b)}$, Tomáš Zachoval ${ }^{(\mathfrak{c})}$ \\ ${ }^{(a, c)}$ Department of Software Technologies, FEI, University of Pardubice, Pardubice, Czech Republic \\ (b) VHRoušar, s.r.o., Pardubice, Czech Republic
}

(a) $\underline{\text { Jan.Fikejz@upce.cz }},{ }^{(\mathrm{c})} \underline{\text { rousar@vahrousar.cz, }},{ }^{(\mathrm{c})}$ Tomas.Zachoval@ student.upce.cz,

\begin{abstract}
This article deals with the use of a computer simulation to solve the protective function of a flood-control reservoir as a support tool for flood wave transformation. Attention is primarily focused on the design and implementation of a simulation tool enabling to implement selected mathematical approach for numerical solution of the balance equation of inflow, outflow and retention of water in the reservoir. The designed software tool is then used for the selected experiment of transformation of theoretical flood wave by flood-control reservoir.
\end{abstract}

Keywords: computer simulation, flood-control reservoir, flood wave transformation

\section{INTRODUCTION}

Flood-control reservoir or polders are hydraulic structures designed to protect human health, property and the environment from the effects of floods. Due to global climate change, there have been changes in the approach in the field of protection against extreme and torrential floods in recent decades. These are reservoirs with design parameters corresponding to small water reservoirs, i.e. with volume up to 2 million $\mathrm{m}^{3}$ and the largest reservoir depth of $9 \mathrm{~m}$ (Doležal et al., 2011). The purpose of the reservoir is to reduce the peak flow rate of the flood and distribute the volume of the flood wave to a longer time interval by temporary water retention. After the flood subsides, the reservoir is emptied. Outside the flood, the reservoir can be dry, without water, or partially filled, the it is so-called semi-dry reservoir, which then has a landscape design and ecological function outside flood events (Ministry of Agriculture, 2005).

To ensure the maximum transformation effect of the reservoirs it is necessary to ensure that the protective space is filled only during the period of the culminating flood wave. Its premature filling in the period of onset of the flood can significantly reduce the retention effect. Therefore, in order to function properly and ensure the greatest transformation effect, it is necessary to design the optimal capacity of the bottom outlets and the emergency spillway parameters in relation to the expected inflow in flood and to the level of flood protection downstream the reservoir.

\section{STATE OF ART}

The transformation of the flood wave can be solved by complex rainfall-runoff model (HYDROG, AquaLog), hydrodynamic numerical model for surface water flow (HEC-RAS, MIKE), graphical Klemeš's method, or mathematical interpretation of the differential equation of the law of mass preservation (balance equation).

The rainfall-runoff models include partial models for the solution of flood wave transformation (Marton, Starý, 2018), but from the point of view of their complexity of solved hydrological phenomena, difficulty in inputting data, and restricted access to the program are not used. Hydrodynamic models of surface water flow solve the transformation of the flood wave by reservoirs by calculating the unsteady flow. To assemble the numerical model, you need to specify the morphology of the reservoir bottom and the parameters of functional objects. To build the model, however, it is assumed that the user is well versed in the field of hydrodynamic modelling of surface water and has basic knowledge in the field of numerics. Graphic Klemeš's method is the simplest of methods (Starý, 2006), but its construction is time-consuming and is not suitable for optimization tasks. The mathematical interpretation of the differential balance equation can be done by tabular calculation e.g. in a spreadsheet, but the accuracy of the calculation is mainly limited by the length of the time step (Doležal et al., 2011). Therefore, the authors of the article develop their own simulation program interpreting the differential balance equation (Roušar, 2015) without the limitation of the time step, with a friendly user interface (Zachoval, 2019) enabling a clear input of data and a choice of contemporary hydraulic relations for optimization of functional objects and solutions of protective function of flood-control reservoir (Yaraghi et al. 2019).

\section{FLOOD WAVE TRANSFORMATION}

To solve the transformation of a flood wave, a mathematical apparatus based on the balance equation of inflow, outflow and retention of water in the reservoir is 
used. This equation is mathematically expressed as ordinary differential equation (relationship 1),

$$
\frac{d V}{d t}=Q-O
$$

where the left element of the equation denotes the change in volume $V$ for time $t, Q$ is the inflow, and $O$ is the outflow. The inflow represents the hydrograph of the flood wave, where $Q=\mathrm{f}(t)$. The outflow depends on the current water level, the parameters of functional objects and, if necessary, the manipulation rules of the reservoir.

Equation (1) is further approximated by Euler's explicit scheme (Moin, 2010) according to relation (2).

$$
V_{i+1}-V_{i}=\left(Q_{i}-O_{i}\right) \Delta t
$$

with an approximation error in the time step $\Delta t$. To solve equation (2), an initial condition representing the filling of the reservoir is necessary

$$
V(i=0)=V_{0}
$$

\subsection{Bathygraphy}

In order to solve equations (2) and (3) it is necessary to specify the characteristics of the reservoir in the form of bathygraphy. This is a description of the flooded area of the reservoir expressed by the dependence of the position of the water level and its corresponding flooded area or the corresponding total volume of water in the reservoir. Bathygraphy expressed in volume and area of water is shown in Figure 1.

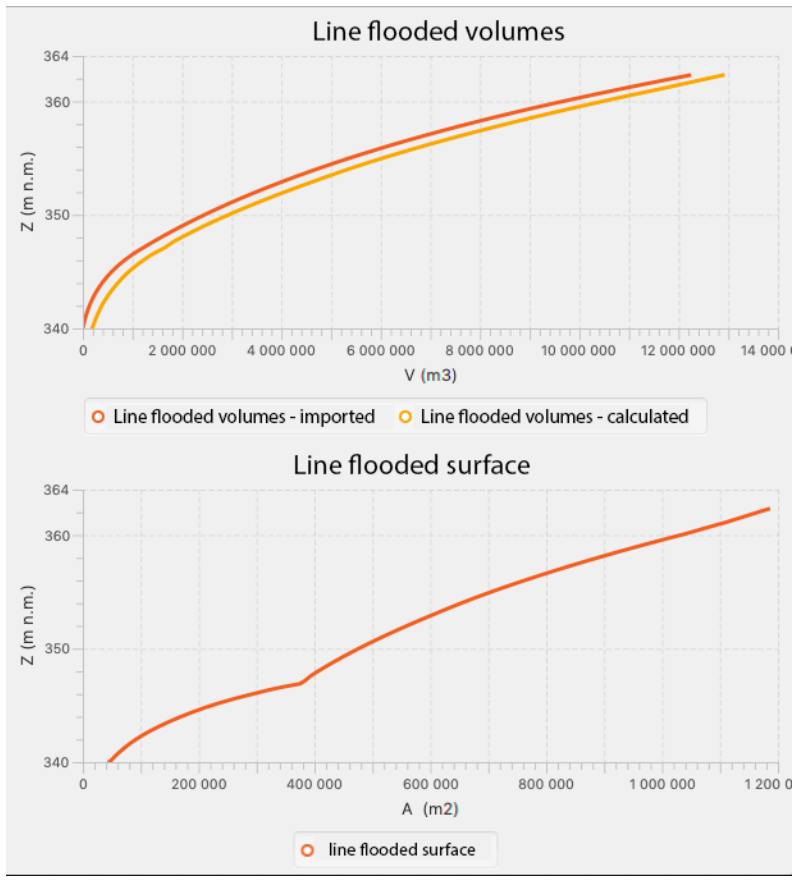

Figure1: Bathygraphy of the reservoir

\subsection{Hydrograph}

The flood wave hydrograph represents the volume of water poured into the reservoir for the duration of the wave. The flood wave is evaluated for individual Nyears, which differ from each other not only by the volume and duration of the wave, but also by the maximum peak flow and shape of the hydrograph. The hydrograph is entered in the program as a flow dependency for the corresponding time step of the flood wave, see Figure 2.

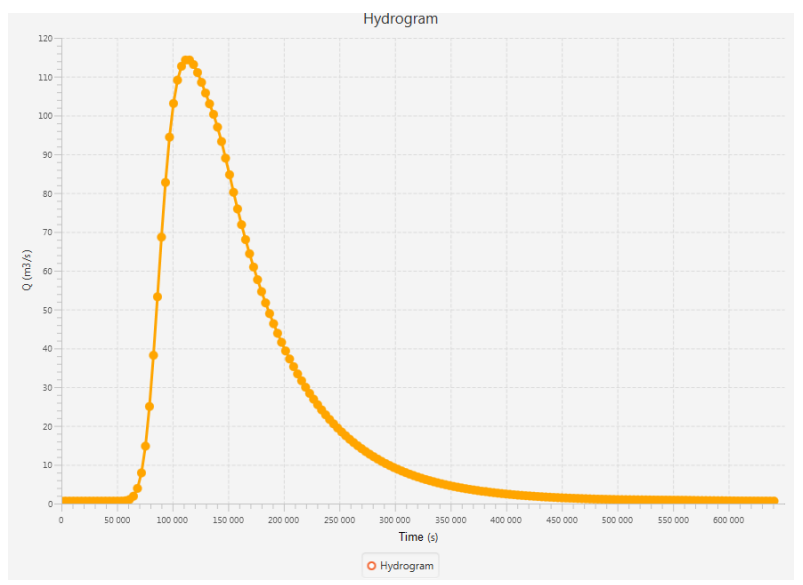

Figure 2: Hydrograph of a flood wave

The outflow of water from the reservoir is determined as the sum of the sub-outflows of the bottom outlets and emergency spillways. In the program it is possible to specify different parameters for up to three objects from each. It is assumed that the bottom outlet is still open. The outflow through the emergency spillway shall only take place until the position of the water level in the reservoir exceeds overflow edge level of the emergency spillway.

The bottom outlet discharge $O_{s}$ is

$$
O_{s}=\mu A \sqrt{2 g H}
$$

where $\mu$ is the bottom outlet discharge coefficient, $A$ is the cross-sectional area at the end of the outlet, $g$ is the gravity acceleration, and $H$ is the difference between the upstream water level and the outlet axis.

The emergency spillway discharge $O_{p}$ is

$$
O_{p}=m b_{0} \sqrt{2 g} h^{\frac{3}{2}}
$$

where $m$ is the discharge coefficient, $b_{0}$ is the effective spillway width and $h$ is the head on the spillway crest.

\section{DESIGN OF A SIMULATION TOOL}

A simulation software tool was designed for the purposes of the flood-control reservoir simulation, which enables a wide range of parameterization of functional objects (outlets and spillways). Some parameters of functional objects can be entered as input constants, or they can be calculated using appropriate mathematical relationships based on the physical parameters of the given object. The 
designed simulation software tool contains a core of discrete simulation, which, according to the simulation time step, performs individual iterations of the calculation.

The simulation tool allows to simulate the behaviour of the flood-control reservoir based on input parameters according to selected simulation scenarios. These include three areas of inputs:

- Flood wave - entered using a hydrograph

- Shape of the valley of the situated dam according to the bathygraphy curves

- Functional object group:

$$
\begin{array}{ll}
\circ & \text { Outlets } \\
\circ & \text { Spillways }
\end{array}
$$

\subsection{Outputs}

Each simulation scenario compiles the results in text and graphical form. Simulation output data are the values of the quantities observed at the reservoir at a specific time, observing the following values:

- $\Delta t \quad$ - time step (s)

- $Q \quad$ inflow $\left(\mathrm{m}^{3} / \mathrm{s}\right)$

- $H \quad$ - water level (above sea level)

- $V \quad$ - volume $\left(\mathrm{m}^{3}\right)$

- $O \quad$ - outflow of individual functional objects $\left(\mathrm{m}^{3} / \mathrm{s}\right)$

- $d V / d t \quad$ - volume change over time

- $d V \quad$ - volume change

\section{THE CONCEPT OF THE CALCULATION} ALGORITHM

The simulation core uses a designed calculation algorithm that can be divided into several steps:

1. The calculation time step $(\Delta t)$ is determined based on the parameter specified by the user before starting the calculation. In practice, this step corresponds to a range of 1-100 seconds.

2. The inflow $(Q)$ is taken from the hydrograph based on time. If the required time is not present in the hydrograph, then the inflow $Q$ is interpolated by linear interpolation from the closest two values.

3. The volume $(V)$ for the initialization time $t_{0}$ based on the height of the water level in the reservoir is determined from the bathygraphy curves. In other simulation times, the volume is calculated from the flow and outflow difference.

4. The water level $(H)$ at the time $t_{0}$ is determined from the parameter specified by the user before starting the calculation. In other simulation times it is determined from the bathygraphy curves, based on the current volume. If the given volume value is not found in the bathygraphy curves, then the water level is linear interpolated from the closest two values.

5. The outflow of outlet/outlets $\left(O_{s}\right)$ is calculated based on the parameters of the particular outlet and the height of the water level in the reservoir, always for the current time point of the simulation calculation.

6. Outflow of spillway/spillways $\left(O_{p}\right)$ is calculated based on the parameters of the specific spillway, always for the current time point of the simulation calculation.

7. Then the calculation of volume difference $(d V)$ according to relation (7) is performed as a ratio of the sum of outflows from functional objects $\left(\sum O\right.$ relation 6$)$ and inflow $(Q)$. This difference is then multiplied by the time step value $(t)$. Negative difference indicates that the inflow is larger than the outflow, and vice versa.

$$
\begin{aligned}
& \sum O=\sum O_{S}+\sum O_{P} \\
& d V=\left(\sum O-Q\right) \Delta t
\end{aligned}
$$

8. The water volume in the flood-control reservoir for the next simulation step $(V(i+1))$ is given by the sum of the current volume value $(V(i))$ and the volume difference in the observed time step $(d V)$, relationship 8.

$$
V(i+1)=V(i)+d V
$$

9. If the simulation calculation was implemented for all time moments, then it can be declared completed. However, if during the simulation there is a situation where the value of volume of water in the flood-control reservoir is greater than its maximum volume indicated in the bathygraphy curves then the flood-control reservoir overflows and the simulation is terminated.

\subsection{Verification and validation}

For the verification and validation of design approach for simulation of balance equation of inflow, outflow and retention of water in the reservoir was used verification calculations on historical data of selected dams. The subparts of implemented equations were vitrificated and consulted by expert on hydrogeology. As technical software tools were utilized MS Excel and Matlab.

\section{EXPERIMENTS}

As part of the experiments, an already existing floodcontrol reservoir was tested from the perspective of potential reconstruction and reconfiguration of the 
current spillway, which in conditions of changing climate and nature of precipitation may appear as no longer satisfactory in the future.

The simulation was considered for the flood wave, which is described by the hydrograph, see Figure 3

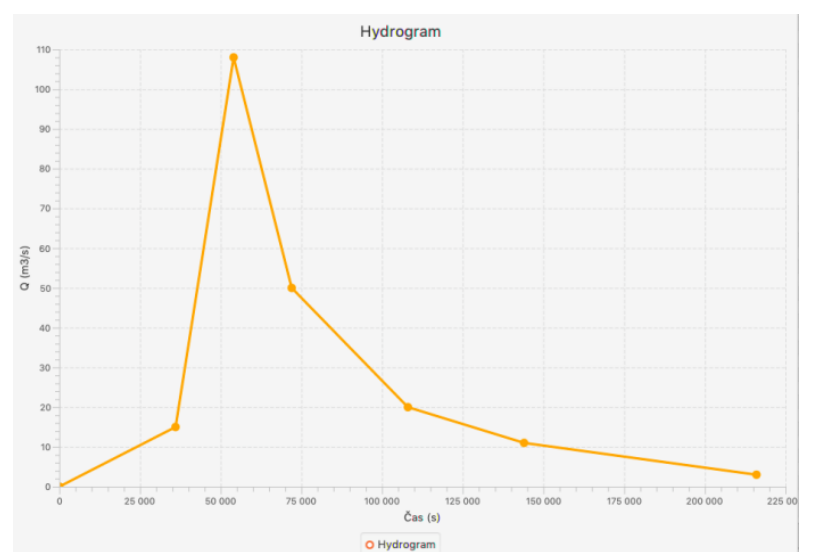

Figure 3: Input hydrograph

The shape and capacity of the flood-control reservoir is described in the bathygraphy curve shown in Figure 4.

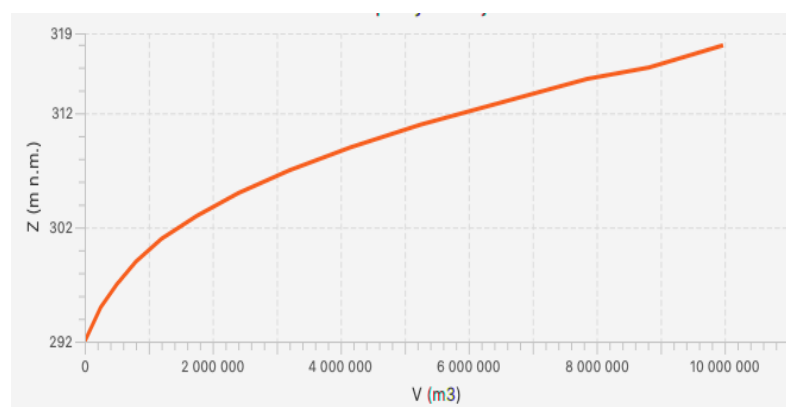

Figure 4: Bathygraphy curve of the flood-control reservoir

The longitudinal profile of the observed flood-control reservoir is shown in Figure 5 (Kratochvíl and Stara 1987)

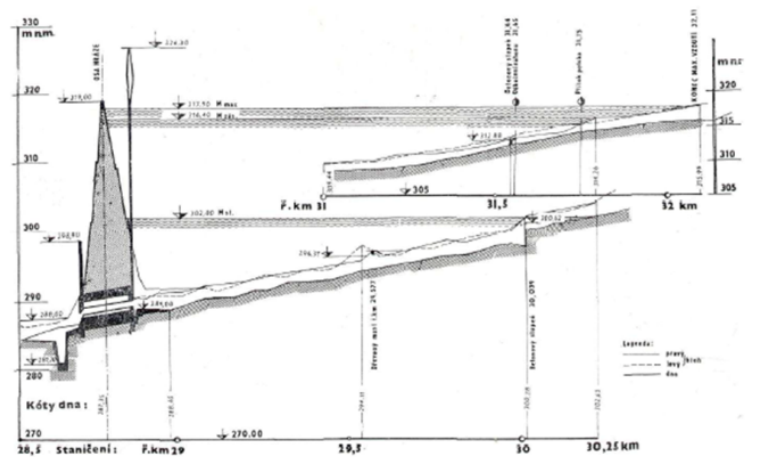

Figure 5: Longitudinal profile of the dam

and it has the following parameters:

- Crest of the dam: $319 \mathrm{~m}$ above sea level

- Maximum level (Hmax): $317.9 \mathrm{~m}$ above sea level
- Maximum storage space: $316.4 \mathrm{~m}$ above sea level

- Level before the arrival of the flood wave: 315.5 $\mathrm{m}$ above sea level

The flood-control reservoir will have two functional objects, namely:

- Outlet:

○ Outlet diameter: $0.8 \mathrm{~m}$

○ Outlet bottom dimension: $288.1 \mathrm{~m}$ above sea level

○ Outflow factor $\mu$ : 0.416

- Spillway

○ Spillway dimension: $316.4 \mathrm{~m}$ above sea level

○ Spillway width: subject to simulation

○ Spillway factor m: 0.51

The aim of this selected simulation was to examine various variations in the of spillway width so as to avoid uncontrolled overflow of the flood-control reservoir, as well as to ensure that the total water outflow through functional objects was less than $40 \mathrm{~m}^{3} / \mathrm{s}$. With a total outflow larger than $40 \mathrm{~m}^{3} / \mathrm{s}$, the residential area under the flood-control reservoir would already be flooded. The range of the checked spillway width was established to be from 4 to 35 metres. In Figure 7, we can see the partial results of the simulation experiment for a spillway width of 10 meters.

The final results of the experiment are then shown in Figure 6. From these values it is clear that for the tested flood wave it is possible to consider the spillway width of 6-17 meters. For the spillway width of less than 6 meters, there is already an uncontrolled overflow of the flood-control reservoir. For a spillway width of more than 17 metres, the flow is already above $40 \mathrm{~m}^{3} / \mathrm{s}$, which would already result in flooding of residential and industrial premises under the flood-control reservoir.

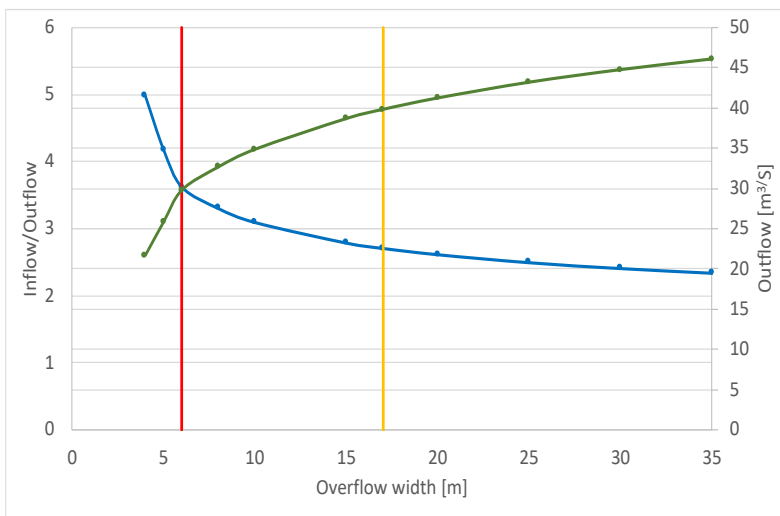

_-Inflow/Outflow -Dam overflow —Over-limit flow (40 m3/s) -Max outflow

Figure 6: Experiment Results 


\section{CONCLUSION}

As the climate changes, the nature of rainfall that affects our landscape changes as well. A part of the solution of flood control measures is the construction and utilisation of flood-control reservoirs. These allow to transform flood waves to protect human health, property and the environment. It is therefore important to have software tools available for the design and reconstruction of floodcontrol reservoirs to help us examine various flood situations and propose functional changes. The primary goal was to design and implement a simulation tool enabling to implement selected mathematical approach for numerical solution of balance equation of inflow, outflow and flood-control of water in the reservoir.

The designed software tool was then used for experiments in the transformation of a flood wave by a flood-control reservoir. As part of the experiment, an already existing flood-control reservoir was tested from the perspective of potential reconstruction and reconfiguration of the current spillway, which in conditions of changing climate and nature of precipitation may appear as unsatisfactory in the future. The results of the experiment were then transferred into a graphic form. From these values it is clear that for the tested flood wave it is possible to consider the spillway width of 6-17 meters. For the spillway width of less than 6 meters, there is already an uncontrolled overflow of the flood-control reservoir. For a spillway width of more than 17 metres, the flow is already above the boundary $40 \mathrm{~m}^{3} / \mathrm{s}$, which would already result in flooding of residential and industrial premises under the floodcontrol reservoir.

\section{ACKNOWLEDGMENTS}

The work was supported by the funds of the University of Pardubice, Czech Republic - Student grant competition (SGS_2019_021)

\section{REFERENCES}

ČSN 752935 Posuzování bezpečnosti vodních děl při povodních. Leden 2014. 16 str.

Doležal, P., Golík, P, Říha, J., Torner, V., Žatecký, S. Malé vodní a suché nádrže. Technická pomůcka $\mathrm{k}$ činnosti autorizovaných osob, TP 1.19. Praha, 2011. Str. 108. ISBN 978-80-86364-16-2.

Kratochvíl, J., Stara, V. Projektování přehrad, Komplexní projket HT. ES VUT scripts, 1987 101paages.

Marton, D., Starý M. Posouzení funkčních objemů vodního díla Vír I na aktualizovaná vstupní data. VTEI, 2018, 2. ISSN 1805-6555.

Ministerstvo zemedělství. Suché a polosuché poldry. Katalog opatření 35. Prosinec 2005. 5 str.

Moin, P. Fundamentals of engineering numerical analysis. Second edition. Cambridge university press, 2010. ISBN 978-0-521-26967-4.

Roušar, L. Studie odtokových poměrů - Horni Bradlo. Hydrotechnické výpočty. Červen, 2015. 18 str.

Starý, M. Nádrže a vodohospodářské soustavy. Modul 01. VUT Brno, 2006. 120 str.

TNV 752415 Suché nádrže. Leden 2013. 19 str.

Yaraghi, N, Ronkanen, A., Darabi, H., Kløve B., and Torabi Haghighi, A. Impact of managed aquifer recharge structure on river flow regimes in arid and semi-arid climates. Science of The Total Environment [online]. 2019, 675, 429-438 ISSN 00489697.

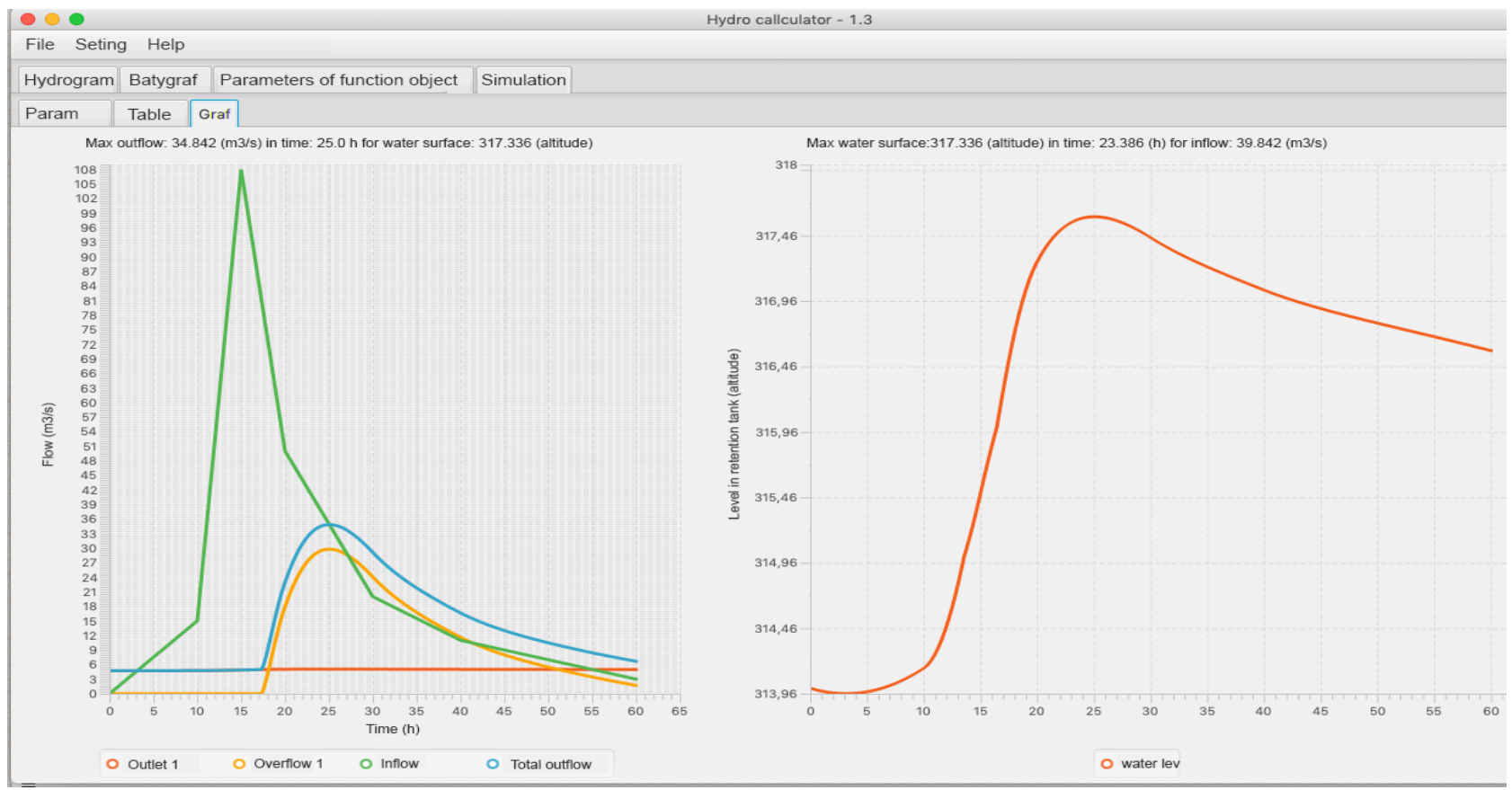

Figure 7: Runing application 